\title{
IMPLEMENTASI PRINSIP DEMOKRASI DAN NOMOKRASI DALAM STRUKTUR KETATANEGARAAN RI PASCA AMANDEMEN UUD 1945
}

\author{
Martha Pigome \\ Fakultas IImu Sosial dan IImu Politik Universitas Satya Wiyata Papua \\ E-mail: pigomemartha@yahoo.co.id
}

\begin{abstract}
The principle of democracy and nomocracy as state in the Constitution 1945 is the embodiment of the state that based on civil sovereignty and state characteristics that uphold the law. Implemention of those two principles changes the structure of the state that established the Constitutional Court. This institution known as the guardian of democracy of any process of political democatization and legal policy. The consitutional Court plays an important role in maintaining the state constitution (Constitution 1945). Constitutional Court have an authority to solve dispute elections and general election. This institution also have a role to judicial review of any statute that not synchronize with the Constitution 1945.
\end{abstract}

Keywords : Demoratization, Rule of Law, Constitution and Legal Policy

\begin{abstract}
Abstrak
Prinsip demokrasi dan nomokrasi sebagaimana tertuang dalam UUD 1945 merupakan perwujudan dari ciri negara yang berdasarkan atas kedaulatan rakyat dan ciri negara yang menjunjung tinggi hukum atau berdasarkan atas hukum. Dalam implementasi kedua prinsip diatas mempengaruhi perubahan dalam struktur ketatanegaraan dimana terbentuknya lembaga Mahkamah Konstitusi (MK). Lembaga negara ini bertujuan sebagai Pengawal Demokrasi dan Penegak Konstitusi dari setiap proses demokratisasi dan Politik Hukum (Nasional). Mahkamah Konstitusi berperan penting dalam mempertahankan konstitusi negara (UUD 1945). Mahkamah Konstitusi sebagai pengawal demokrasi berwenang menyelesaikan dan memutuskan sengketa Pemilu dan Pemilukada. Sebagai penegak konstitusi, lembaga ini berperan melakukan judicial review terhadap setiap produk undang-undang yang bertentangan dengan UUD 1945.
\end{abstract}

Kata Kunci : Demokratisasi, Negara Hukum, Konstitusi dan Politik Hukum

\section{Pendahuluan}

Lahirnya Amandemen Undang-Undang Dasar 1945 (UUD 1945) merupakan wujud dari Reformasi Politik dan Reformasi Konstitusi yang berjalan secara demokratis. Era Reformasi ditandai dengan dilakukannya reformasi Politik dan Reformasi Konstitusi. Secara teoritis, suatu konstitusi dapat diubah dalam rangka penyempurnaan. Upaya penyempurnaan atas kekurangan yang terdapat dalam suatu konstitusi, dapat dilakukan melalui formal amandement, constitutional convention ataupun yudicial interpretation.

Reformasi konstitusi dilakukan karena terdapat beberapa aspek kelemahan yang terdapat dalam UUD 1945 sehingga menyebabkan tidak demokratisnya negara Indonesia selama ini. Pertama, UUD 1945 membangun sistem politik yang executive heavy dengan memberi porsi yang sangat besar kepada kekuasaan Presiden tanpa adanya mekanisme checks and balance yang memadai; kedua, UUD 1945 terlalu banyak memberi atribusi dan delegasi kewenangan kepada Presiden untuk mengatur lagi hal-hal penting dengan Undang-Undang maupun Peraturan Pemerintah; ketiga, UUD 1945 memuat beberapa pasal ambigu atau multitafsir sehingga bisa ditafsirkan dengan bermacammacam tafsir tetapi tafsir yang harus diterima adalah tafsir yang dibuat oleh Presiden; dan keempat, UUD 1945 lebih mengutamakan semangat penyelenggaraan negara dari pada sis- 
temnya. Dalam mengatasi kelemahan-kelemahan UUD 1945 maka sejak reformasi telah dilakukan perubahan UUD 1945 sebanyak 4 (empat) kali yaitu perubahan pertama dilakukan oleh Majelis Permusyawaratan Rakyat (MPR) pada tanggal 9 Oktober 1999, perubahan kedua dilakukan oleh MPR pada tanggal 18 Agustus 2000, perubahan ketiga dilakukan oleh MPR pada tanggal 9 Nopember 2001, perubahan keempat dilakukan oleh MPR pada tanggal 10 Agustus 2002.

Demokrasi sebelum amandemen UUD 1945, ditandai dengan kedaulatan yang berada di tangan rakyat dan dijalankan oleh MPR tetapi sebagaimana terdapat dalam Pasal 1 ayat (2), kedaulatan tertinggi berada di tangan rakyat dan dijalankan berdasarkan UUD. Demikian halnya dengan nomokrasi, Pasal 1 ayat (3) berbunyi negara Indonesia adalah negara hukum. Sebelumnya, yang dikenal adalah negara berdasarkan atas hukum (Rechtsstaat). Konsep ini merupakan penjabaran dari konsep Rule of Law (ROL), dengan berpedoman pada sistem hukum Eropa Continental.

Negara hukum yang demokratis antara demokrasi dan nomokrasi, jika dianut bersamasama dalam sebuah negara akan melahirkan konsep negara hukum yang demokratis. Dari sisi pemahaman kedaulatan rakyat, kekuasaan tertinggi dalam suatu negara berada di tangan rakyat. Kekuasaan tertinggi di tangan rakyat itu dibatasi oleh kesepakatan yang mereka tentukan sendiri secara bersama-sama yang dituangkan dalam aturan hukum yang berpuncak pada rumusan konstitusi sebagai produk kesepakatan tertinggi dari seluruh rakyat.

Proses inilah yang secara teoretis disebut kontrak sosial antara seluruh rakyat. Aturan hukum membatasi dan mengatur bagaimana kedaulatan rakyat itu disalurkan, dijalankan, dan diselenggarakan dalam kegiatan kenegaraan dan pemerintahan. Inilah yang kemudian berkembang menjadi doktrin negara hukum. Sebaliknya hukum harus mencerminkan kepentingan dan perasaan keadilan rakyat. Oleh karena itu, hukum harus dibuat dengan mekanisme demokratis. Hukum tidak boleh dibuat untuk kepentingan kelompok tertentu atau kepentingan penguasa yang akan melahirkan negara hukum yang totaliter.

Hukum tertinggi di sebuah negara adalah produk hukum yang paling mencerminkan kesepakatan dari seluruh rakyat, yaitu konstitusi. Dengan demikian, aturan dasar penyelenggaraan negara yang harus dilaksanakan adalah konstitusi. Bahkan, semua aturan hukum lain yang dibuat melalui mekanisme demokrasi tidak boleh bertentangan dengan konstitusi. Hal ini karena aturan hukum yang dibuat dengan mekanisme demokrasi tersebut adalah produk "mayoritas rakyat", sedangkan konstitusi adalah produk "seluruh rakyat". Dengan demikian, dalam konsep negara hukum yang demokratis terkandung makna bahwa demokrasi diatur dan dibatasi oleh aturan hukum, sedangkan substansi hukum itu sendiri ditentukan dengan caracara yang demokratis berdasarkan konstitusi. Demokrasi dan nomokrasi menyatukan pendekatan kuantitatif dalam mekanisme demokrasi dan pendekatan logika kebenaran dan keadilan hukum berdasarkan kehendak seluruh rakyat yang tertuang dalam konstitusi.

Indonesia sebagai Negara Hukum yang Demokratis, menganut kedaulatan rakyat sekaligus kedaulatan hukum. Sebagai negara hukum, segala tindakan penyelenggara negara dan warga negara harus sesuai dengan aturan hukum yang berlaku. Hukum dalam hal ini adalah hierarki tatanan norma yang berpuncak pada konstitusi, yaitu UUD 1945. Dengan demikian, pelaksanaan demokrasi juga harus berdasarkan pada aturan hukum yang berpuncak pada UUD 1945. Sebagai pelaksanaan dari konsepsi negara hukum yang demokratis, diterapkan prinsip saling mengimbangi dan mengawasi antara lembaga negara (check and balances system).

Berdasarkan uraian diatas, maka tulisan ini dimaksudkan untuk menjelaskan tentang prinsip demokrasi dan nomokrasi dalam Amandemen UUD 1945 dan implementasi dari prinsip demokrasi dan nomokrasi dalam struktur ketatanegaraan pasca amandemen UUD 1945.

\section{Pembahasan}




\section{Konsep Demokrasi, Nomokrasi Dan Politik Hukum Nasional}

Konsep 'nomocracy' yang berasal dari perkataan 'nomos' dan 'cratos'. Perkataan nomokrasi dapat dibandingkan dengan 'demos' dan 'cratos'/ 'kratien' dalam demokratis. 'Nom os' berarti norma, sedangkan 'cratos' adalah kekuasaan sebagai faktor penentu dalam penyelenggaraan kekuasaan adalah norma atau hukum. Oleh karena itu, istilah nomokrasi berkaitan erat dengan ide kedaulatan hukum atau prinsip hukum sebagai kekuasaan tertinggi.

Demokrasi tidak dapat dibicarakan secara terpisah atau tanpa mengaitkannya dengan konsep negara hukum, karena negara hukum merupakan salah satu negara demokratis, dan demokratis merupakan salah satu cara paling aman untuk mempertahankan kontrol atas negara hukum (negara hukum yang berdemokratis). Gagasan dari negara hukum adalah bahwa hukum negara harus dijalankan dengan baik dalam arti sesuai dengan apa yang diharapkan oleh masyarakat terhadap hukum) dan adil (karena maksud dasar dari hukum adalah keadilan). ${ }^{1}$ Secara substansial, makna demokrasi dari kaca mata hukum ada dua yakni berkaitan dengan norma berupa cara memperoleh kekuasaan dan bagaimana melaksanakan kekuasaan. $^{2}$

Kedaulatan rakyat (demokrasi) sebagaimana diatur dalam pasal 1 Ayat (2) dan kedaulatan hukum (nomokrasi) diatur dalam Pasal 1 Ayat (3) UUD 1945 merupakan dua hal yang mempunyai hubungan keterkaitan dan tidak bisa dipisahkan dalam negara demokratis yang menjunjung tinggi hukum dan keadilan seperti Indonesia.

\section{Sistem Demokrasi atau Demokratisasi}

Setelah adanya perubahan sistem demokrasi sebagaimana terdapat dalam Pasal 1 Ayat (2) UUD 1945, ditandai dengan demokrasi se-

\footnotetext{
1 Arief Hidayat, Bernegara Itu Tidak Mudah (Dalam Perspektif Politik Dan Hukum), Pidato Pengukuhan Guru Besar Dalam IImu Hukum FH Undip Semarang, 4 Februari 2010, hlm. 30

2 Zulfirman, "Ontologi Demokrasi", Jurnal Hukum 14 (2) J uni 2006, FH Universitas Sultan Agung (UNISULA) Semarang, hlm. 137-138
}

cara langsung oleh rakyat, dari rakyat dan untuk rakyat maka kepala negara yang sebelum Amandemen dipilih oleh MPR RI, telah berubah dimana dipilih langsung oleh rakyat melalui pemilihan presiden dan wakil presiden bahkan kepala daerah (pemilukada). Demokratisasi bertujuan untuk menciptakan keadilan dalam berpolitik. Di samping itu demokrasi dapat mewujudkan keadilan sosial bagi seluruh rakyat Indonesia baik dibidang politik, ekonomi dan lain-lain. Demokrasi dibidang ekonomi disebut demokrasi ekonomi. ${ }^{3}$ Demokrasi politik dan demokrasi ekonomi oleh Bung Karno di sebut sebagai Socio-Demokrasi. ${ }^{4}$

Sejak berlakunya Undang-Undang Nomor 22 Tahun 2007 tentang Penyelenggara Pemilihan Umum (pemilu), dan UU No. 10 Tahun 2008 tentang Pemilihan Umum Anggota Dewan Perwakilan Rakyat Republik Indonesia (DPR RI), Dewan Perwakilan Daerah (DPD) dan Dewan Perwakilan Rakyat Daerah (DPRD), pemilihan kepala derah secara langsung (pemilukada) dimasukkan dalam rezim pemilu, sehingga secara resmi bernama "pemi-lihan umum kepala daerah dan wakil kepala daerah". Berdasarkan Undang-Undang Nomor 32 Tahun 2004, peserta pemilukada adalah pasangan calon yang diusulkan oleh partai politik atau gabungan partai politik. Ketentuan ini diubah dengan UndangUndang Nomor 12 Tahun 2008 yang menyatakan bahwa peserta pemilukada juga dapat berasal dari pasangan calon perseorangan yang didukung oleh sejumlah orang. Undang-undang ini menindaklanjuti keputusan Mahkamah Konstitusi yang membatalkan beberapa pasal menyangkut peserta Pemilukada dalam UndangUndang Nomor 32 Tahun 2004 dengan beberapa perubahan pasal-pasal dalam UU ke dalam UU No. 12 Tahun 2008 tentang Pemerintahan Dae-

Novita Dewi Masyithoh, "Kebijakan Pemerintah Daerah Dalam Pemberdayaan Ekonomi Perempuan Sebagai perwujudan Ekonomi Kerakyatan (Studi Kelompok Wanita Tani Ngaliyan Kecamatan Limpung Kabupaten Batang)", J urnal Law Reform Pembaharuan Hukum, 3 (2) Oktober 2007, Program Magister IImu Hukum Semarang, hlm. 41

4 Djauhari, "Konsep Negara Kesejahteraan Pra Kemerdekaan RI", J urnal Hukum 16 (2), J uni 2006, FH UNISULA Semarang, hlm. 323 
rah. Khusus di Nanggroe Aceh Darussalam, peserta Pilkada juga dapat diusulkan oleh partai politik lokal. Dengan adanya perubahan sistem demokrasi dan nomokrasi sebagaimana tercantum dalam UUD 1945, maka telah membawa konsekuensi perubahan dalam sistem ketatanegaraan.

MPR RI sebelum Amandemen UUD 1945 sebagai lembaga tertinggi negara namun dalam truktur ketatanegaraan baru kedudukan MPR sama dengan lembaga tinggi lainnya disamping Dewan Perwakilan Rakyat (DPR), Badan Pemeriksa Keuangan (BPK), Mahkamah Konstitusi, Presiden, dan Mahkamah Agung (MA). Salah satu tugasnya adalah melantik dan memberhentikan presiden dan/atau wakil Presiden hasil pemilu secara langsung oleh rakyat berdasarkan UU No. 42 Nomor 2008 tentang Pemilu Presiden dan Wakil Presiden. Lembaga yang menyelenggarakan Pemilu Anggota Dewan Perwakilan Rakyat Republik Indonesi, Dewan Perwakilan Daerah (DPD) dan Dewan Perwakilan Rakyat Daerah (DPRD), dan Pemilu Presiden dan Wakil Presiden dan Pemilu Kepala Daerah dilaksanakan oleh KPU sebagai lembaga independen yang terlepas dari pengaruh pemerintah. Sebelum berlakunya UU No. 12 tahun 2003, Pemilu dilaksanakan oleh Pemerintah dalam hal ini Menteri Dalam Negeri (Depdagri). Tetapi setelah berlakunya UU No. 12 tahun 2003 penyelenggara Pemilu dilakukan oleh Komisi Pemilihan Umum sampai sekarang.

\section{Negara Hukum (Nomokrasi)}

Adanya perkembangan negara hukum modern yang bercirikan rule of law (ROL) dan perkembangan hukum yang mempengaruhi Indonesia bukan saja yang berasal dari rechtsstaat tetapi juga rule of law maka dalam rangka keadilan substantif yang digali dari nilai-nilai masyarakat oleh hakim/ yuris maka negara hukum yang terdapat dalam Pasal 1 Ayat (3) Amandmen UUD 1945 menggabungkan antara rechtsstaat dan rule of law. Konstitusi (UUD) sebagai landasan bersama berbangsa dan ber- negara yang akhirnya melahirkan UUD $1945 .^{5}$ UUD 1945 menjadi sumber tertib hukum. Artinya bahwa dalam pembuatan maupun pemberlakuan peraturan perundang-undangan tidak boleh bertentangan dengan UUD 1945 bahkan dijadikan sebagai sumber atau dasar hukum dari suatu produk peraturan.

Indonesia telah memiliki ciri-ciri sebagai negara hukum. Pertama, supremasi hukum (supremacy of law) diatur dalam Pasal 1 ayat (3) UUD 1945; kedua, kesetaraan dihadapan hukum (equality before the law) diatur dalam Pasal 27 ayat (1) UUD 1945, dan penegakan hukum dengan cara yang tidak bertentangan dengan hukum (due process of law) diatur dalam pasal 24 UUD 1945. Prinsip negara hukum yang dianut oleh Negara Kesatuan Republik Indonesia (NKRI) adalah "Negara Hukum Pancasila" yang bersifat prismatik dan integratif, yaitu prinsip negara hukum yang mengintegrasikan atau menyatukan unsur-unsur yang baik dari beberapa konsep yang berbeda (rechtsstaat, the rule of law, konsep negara hukum formil dan materiil) dan diberi nilai keindonesiaan (seperti kekeluargaan, kebapakan, keserasian, keseimbangan dan musyawarah merupakan akar dari budaya hukum Indonesia) sehinga menjadi prinsip “Negara Hukum Pancasila".

Konsekuensi sebagai negara hukum, secara mutatis mutandis memunculkan kewajiban bagi negara, untuk melaksanakan prinsip keadilan. Prinsip keadilan dalam negara hukum tersebut, berusaha untuk mendapatkan titik tengah antara dua kepentingan, memberikan kesempatan kepada negara untuk menjalankan pemerintahan dengan kekuasaannnya, tetapi pada sisi lain masyarakat harus mendapat perlindungan atas hak-haknya melalui prinsip keadilan hukum. ${ }^{6}$ Dengan masuknya Indonesia sebagai negara hukum dalam dalam pasal UUD 1945 memperkuat posisi UUD 1945 sebagai

5 Fatkhurohman, "Memahami Pembubaran Partai Politik Era Orde Lama Di Indonesia", J urnal Media Hukum 16 (2) Desember 2009, FH Universitas Muhammadiyah Yogyakarta, hlm. 319

6 Yos J ohan Utama, Membangun Peradilan Tata Usaha Negara Yang Berwibawa, Pidato Pengukuhan Guru Besar Dalam IImu Hukum Undip Semarang, 4 Februari 2010, hlm. 5 
konstitusi negara yang harus dipertahankan dan ditegakkan. Di sinilah peran dari lembaga judisial yakni Mahkamah Konstitusi dalam menegakkan konstitusi (UUD 1945) tersebut.

\section{Politik Hukum Nasional}

Setelah melewati proses Pemilu, maka DPR diberi kewenangan legislasi oleh UUD. Pemerintah dapat membuat RUU untuk kemudian diajukan ke DPR untuk dibahas dan ditetapkan menjadi UU disahkan dalam lembaran negara. Oleh karena itu UU merupakan hasil produk politik.

Politik hukum secara sederhana dapat dirumuskan sebagai kebijaksanaan hukum (legal policy) yang akan atau telah dilaksanakan secara nasional oleh pemerintah; mencakup pula pengertian tentang bagaimana politik mempengaruhi hukum dengan cara melihat konfigurasi kekuatan yang ada dibelakang pembuatan dan penegakan hukum itu. Di sini hukum tidak dapat hanya dipandang sebagai pasal-pasal yang bersifat imperatif atau keharusan-keharusan yang bersifat das sollen, melainkan harus dipandang sebagai sub sistem yang dalam kenyataan (das sein) bukan tidak mungkin sangat ditentukan oleh politik, baik dalam perumusan materi dan pasal-pasalnya maupun dalam implementasi dan penegakannya. Menurut Mahfud MD, Politik hukum adalah legal policy atau arah hukum yang akan diberlakukan oleh negara untuk mencapai tujuan negara yang bentuknya dapat berupa pembuatan hukum baru dan penggantian hukum lama. ${ }^{7}$

Kebijaksanaan hukum (legal policy) inilah yang menjadi tempat berlangsungnya kegiatan politik hukum. Dalam legal policy terdapat pihak-pihak yang mempunyai kepentingan terutama berkaitan dengan pembuatan suatu peraturan perundang-undangan, dalam hal ini adalah eksekutif dan legislatif yang diberi kewenangan oleh UUD sebagai pembuat dan pembentuk UU.

Moh. Mahfud MD, 2006, Membangun Politik Hukum Menegakkan Konstitusi, J akarta: Pustaka PL3ES Indonesia, hlm. 5
Hal tersebut sangat dipengaruhi oleh penguasa yang ada saat itu. Penguasa yang memimpin akan menentukan politik hukum apa yang dapat digunakan dalam setiap legal policy. ${ }^{8}$ Namun arti seperti ini politik hukum harus berpijak pada tujuan negara dan sistem hukum yang berlaku yang terkandung dalam pembukaan UUD 1945, khususnya Pancasila sebagai dasar negara yang secara konktrit tercantum dalam Alinea ke-IV Pembukaan UUD 1945.

Politik hukum adalah "kebijakan hukum (legal policy) yang hendak diterapkan atau dilaksanakan secara nasional oleh suatu pemerintah negara tertentu" atau "kebijakan dasar penyelenggara negara dalam bidang hukum yang akan sedang dan telah berlaku, yang bersumber dari nilai-nilai yang berlaku di masyarakat untuk mencapai tujuan negara yang dicita-citakan". ${ }^{9}$ Dalam melihat dan mengkaji hukum dan politik sangat tergantung dari cara pandang bagaimana melihatnya. Bagi yang memandang hukum dari sudut das sollen (keharusan) bahwa hukum harus merupakan pedoman dalam segala tingkatan hubungan antar anggota masyarakat termasuk kegiatan politik. Bagi yang memandang hukum dari sudut das sein (kenyataan) produk hukum sangat dipengaruhi oleh politik, bukan saja dalam pembuatannya tetapi juga dalam kenyataan empirisnya bahwa kegiatan legislatif (pembuat UU) dalam kenyataanya memang lebih banyak membuat keputusan-keputusan politik dibanding dengan menjalankan pekerjaan hukum yang sesungguhnya lebih-lebih jika pekerjaan hukum itu dikaitkan dengan masalah prosedur.

Apabila selama proses politik hukum itu, menyimpang dari UUD 1945 dan merugikan hakhak orang lain atau kepentingan masyarakat maka dapat dilakukan judicial review pada lembaga Mahkamah Konstitusi. Dengan pengertian lain bahwa politik hukum itu harus ber-

Lihat dan bandingkan dengan Hasnati, "Pertautan Kekuasaan Politik dan Negara Hukum", J urnal Hukum Respublica 3 (1) Tahun 2003, Fakultas Hukum Universitas Lancang Kuning Pekanbaru hlm. 102-113

9 Tundjung $\mathrm{H}$. Sitabuana, "Politik Hukum Penyelesaiaan Masalah Cina Di Indonesia Pada Era Global", Jurnal Masalah-Masalah Hukum 37 (1) Maret 2008, FH Universitas Diponegoro, hlm. 66-67 
dasarkan pada dasar negara yaitu Pancasila, tujuan negara dan UUD 1945 dan dalam setiap membuat politik hukum (UU) lebih mengutamakan kepada peningkatan kesejahteraan seluruh masyarakat Indonesia dengan meilhat unsur kenasionalan. Artinya UU yang dibuat harus mengakomodir kepentingan seluruh daerah dan masyarakat Indonesia (kenasionalan).

\section{Implementasi Prinsip Demokrasi dan Nomo- krasi Dalam Struktur Ketatanegaraan Indone- sia Pasca Amandemen Uud 1945}

Pasal 1 ayat (2) UUD 1945 menegaskan bahwa demokrasi yang merupakan manifestasi kedaulatan rakyat berupa penyerahan kepada rakyat untuk mengambil keputusan-keputusan politik dalam hidup bernegara. Sementara, ayat (3) menyatakan mengenai konsep nomokrasi berupa penyerahan kepada hukum untuk menyelesaikan berbagai pencederaan terhadap demokrasi dan hak-hak rakyat. Dengan mengacu ketentuan yang demikian itu, adalah sebuah keniscayaan untuk membangun dan menegakkan hukum berlandaskan demokrasi dan nomokrasi secara seimbang. Memang, antara demokrasi dan nomokrasi berbicara pada aspek yang berbeda namun bukan berarti tidak dapat diseimbang-kan. Demokrasi akan selalu bicara aspek politik bagaimana menegakkan kedaulatan rakyat, sedangkan nomokrasi berbicara pada per-spektif hukum. Oleh karenanya, kedaulatan rakyat tanpa dikawal hukum dipastikan akan mengarah pada kondisi tidak tidak seimbang.

Demokrasi harus dibangun dalam batasbatas nomokrasi, sebab demokrasi tidak mungkin diwujudkan tanpa adanya rule of law. Demokrasi membutuhkan aturan main yang jelas dan dipatuhi secara bersama. Tanpa aturan main, demokrasi tidak akan pernah mencapai tujuan-tujuan substansialnya. Dalam implementasi prinsip nomokrasi maka konsep negara hukum demokratis, demokrasi diatur dan dibatasi oleh aturan hukum, sedangkan hukum itu sendiri ditentukan melalui cara-cara demokratis berdasarkan konstitusi. Dengan demikian, aturan dasar penyelenggaraan negara, dengan segenap politik hukumnya, harus disandarkan kembali secara konsisten pada konstitusi. Tanpa kecuali, semua aturan hukum yang dibuat melalui meka-nisme demokrasi tidak boleh bertentangan dengan konstitusi. Dengan kata lain negara Indonesia adalah negara hukum sehingga setiap kegiatan politik baik itu demokrasi secara langsung dalam Pemilihan Umum (Pemilu) maupun proses pembuatan Undang-Undang dan implementasinya tidak boleh bertentangan dengan konstitusi atau Undang-Undang Dasar 1945. Bila ternyata dalam kenyataannya Undang-Undang tersebut bertentangan degan konstitusi maka undang-undang itu akan dilakukan judicial review oleh Mahkamah Konstitusi. Hal ini dimaksudkan supaya konstitusi tetap ditegakkan sehingga Mahkamah Konstitusi disebu sebagai lembaga pengawal atau penegak konstitusi.

Amandemen UUD 1945 berusaha memberdayakan rakyat yang direkonstruksi dari berbagai aspek, yakni pertama, aspek penguatan lembaga perwakilan; kedua, aspek eksekutif (proses pemilihan langsung presiden); ketiga, aspek Yudikatif (munculnya MK); ataupun keempat, aspek yang terkait dengan HAM. ${ }^{10}$ Dalam struktur ketatangeraan lahirlah lembaga baru yang dinamakan Mahkamah Konstitusi. Lembaga ini hadir sebagai lembaga penyeimbang antara prinsip demokrasi dan nomokrasi dan disebut sebagai lembaga pengawal demokrasi dan penegak konstitusi.

Terdapat 4 (empat) perubahan penting dalam kekuasaan judikatif atau kekuasaan kehakiman. Pertama, apabila sebelum perubahan UUD 1945 jaminan kekuasaan kehakiman hanya terdapat dalam penjelasannya maka setelah perubahannya jaminan tersebut secara eksplisit disebutkan dalam Batang Tubuh UUD 1945; kedua, Mahkamah Agung dan Iain-lain tidak lagi menjadi satu-satunya pelaksaan kekuasaan kehakiman (judicial power), karena di sampingnya ada Mahkamah Konstitusi yang juga ber-

10 Septi Nur Wijayanti, "Studi Evaluasi Terhadap Amandemen UUD 1945 (Amandemen Sebagai Upaya Pemenuhan Kebutuhan Hukum Masyarakat Indonesia)", Jurnal Media Hukum 16 (2) Desember 2009, FH Universitas Muhammadiyah Yogyakarta, hlm. 232-233 
fungsi sebagai pelaku kekuasaan kehakiman; ${ }^{11}$ ketiga, adanya lembaga baru yang bersifat mandiri dalam struktur kekuasaan kehakiman yaitu Komisi Yudisial yang berwenang mengusulkan pengangkatan Hakim Agung dan mempunyai wewenang lain dalam rangka menjaga dan menegakkan kehormatan, keluhuran martabat serta perilaku hakim; ${ }^{12}$ dan keempat, adanya wewenang kekuasaan kehakiman dalam hal ini dilakukan oleh Mahkamah Konstitusi untuk melakukan pengujian UU terhadap UUD, memutus sengketa kewenangan lembaga negara yang kewenangannya diberikan oleh UUD, memutus pembubaran Partai Politik, dan memutus perselisihan tentang hasil pemilihan umum.

Berdasarkan hal di atas, perubahan UUD 1945 (1999-2002) telah membawa semangat baru dalam sistem ketatanegaraan Indonesia, baik dalam Legislative Power sebagai kekuasaan pembuat UU), kekuasaan eksekutif (executive power sebagai kekuasaan pelaksaan UU maupun kekuasaan Yudikatif (judicial power sebagai kekuasaan kehakiman yang mempertahankan dan menegakkan UU). Dalam sistem kekuasaan kehakiman disamping Mahkamah Agung dan badan-badan peradilan yang berada dibawahnya dalam lingkungan Peradilan umum, lingkungan Peradilan Agama, lingkungan Peradilan Militer dan lingkungan Peradilan Tata Usaha Negara, telah muncul lembaga negara baru yaitu Mahkamah Konstitusi dan Komisi Yudisial sebagai implikasi terhadap perubahan UUD 1945.

Menurut Afiuka Hadjar, dan kawan-kawan $^{13}$, terdapat 4 (empat) hal yang melatarbelakangi pembentukkan Mahkamah Konstitusi.

11 Bandingkan dengan Winahyu Erwiningsing, "Mahkamah Konstitusi (Telaah Terhadap Putusan Mahkamah Konstitusi dan Fungsi Mahkamah Konstitusi dalam Reformasi Hukum)", J urnal IImu Hukum, 9 (1) tahun 2006, Fakultas Hukum UMS Surakarta, hlm. 89

12 Muhammad Fauzan, "Eksistensi Komisi Yudisial Dalam Struktur Ketatanegaraan Republik Indonesia dan Yang Seharusnya Diatur Dalam Peraturan Perundangundangan", J urnal Dinamika Hukum 8 (1) tahun 2008, Fakultas Hukum UNSOED Purwokerto, hlm. 91

13 Afiuka Hadjar dalam Suripto "Wewenang Mahkamah Konstitusional menguji UUD (judicial review)", Jurnal Negarawan, 21 juni 2007, Sekretaris Negara Republik Indonesia.
Pertama, Paham Konstitusionalisme, adalah suatu paham yang menganut adanya pembatasan kekuasaan. Paham ini memiliki dua esensi yaitu sebagai konsep negara hukum bahwa hukum mengatasi kuasaan negara, hukum akan melakukan kontrol terhadap politik serta konsep hak-hak sipil warga negara menyatakan bahwa kebebasan warga negara dan kekuasaan negara dibatasi oleh konstitusi; kedua, sebagai mekanisme check and balance, dimana sebuah sistem pemerintahan yang baik antara lain ditandai dengan adanya mekanisme check and balance dalam penyeleggaraan kekuasaan. Check and balance memungkinkan adanya saling kontrol antara cabang-cabang keuasaan yang ada dan menghindari tindakan-tindakan mengenai tiran dan desentralisasi kekuasaan untuk menjaga agar tidak terjadi tumpang tindih antar kewenangan yang ada. Dengan mendasar pada prinsip negara hukum maka sistem kotrol yang relevan adalah sistem kontrol judicial. Ketiga, Penyelenggaraan negara yang bersih, bilamana sistem pemerintahan yang baik meniscayakan adanya penyelenggaraan negara yang bersih; keempat, perlindungan hak asasi manusia yang menegaskan bahwa kekuasaan yang tidak terkontrol, seringkali melakukan tindakan semena-mena dalam penyelenggaraan dan tidak melakukan hak asasi manusia.

Beberapa pertimbangan dibentuknya Mahkamah Konstitusi sebagaimana ditegaskan dalam UU No. 24 Tahun 2003 tentang Mahkamah Konstitusi adalah sebagai berikut. Pertama, bahwa negara kesatuan RI merupakan negara hukum yang berdasarkan Pancasila dan UUD 1945 bertujuan untuk mewujudkan tata kehidupan bangsa dan negara yang tertib, bersih, makmur dan berkeadilan. Kedua, bahwa Mahkamah Konstitusi sebagai salah satu pelaksana kekuasaan kehakiman mempunyai peranna penting dalam usaha menegakkan konstitusi dan prinsip negara hukum sesuai dengan tugas dan wewenangnya sebagaimana ditentukan dalam UUD 1945. Ketiga, bahwa berdasarkan ketentuan pasal 24C ayat (6) UUD 1945 perlu mengatur tentang pengangkatan dan pember- 
hentian hakim konstitusi, hukum acara, dan ketentuan lainnya tentang Mahkamah Konstitusi. Keempat, bahwa berdarkan pertimbangan sebagaimana dimaksud dalam huruf $a, b$, dan huruf $c$ serta untuk melaksanakan ketentuan pasal III Aturan Peralihan UUD 1945, perlu membentuk UU tentang Mahkamah Konstitusi.

Mahkamah Konstitusi diatur dalam pasal 24 Amandemen UUD 1945 kemudian selanjutnya diatur dalam UU No. 24 Tahun 2003 tentang Mahkamah Konstitusi. Dibentuknya Mahkamah Konstitusi merupakan perwujudan demokrasi secara adil dalam menegakkan Konstitusi. Adapun peran Mahkamah Konstitusi dalam menegakkan prinsip nomokrasi dan demokrasi adalah sebagai berikut.

\section{Mahkamah Konstitusi Sebagai Pengawal Demokratis}

Demokratisasi merupakan penjabaran dari Sila ke-4 Pancasila yang kemudian dituangkan kedalam pasal-pasal UUD 1945. Hal inilah yang harus dipertahankan oleh Mahkamah Konstitusi agar pelaksanaan demokrasi dapat berjalan sesuai asas Luber yaitu langsung, umum, bebas dan rahasia.

Berdasarkan kewenangan yang diberikan oleh UUD dalam pasal 24C tentang memutus pembubaran partai politik, dan memutus perselisihan tentang hasil pemilihan umum dan perselisihan hasil Pemilukada ini sudah membuktikan bahwa Mahkamah Konstiusi terutama sebagai pengawal demokrasi.

Partai politik adalah peserta dalam Pemilu dimana anggotanya duduk menjadi anggota di kursi DPR. Dalam hal ini Mahkamah Konstitusi harus mampu melindungi hak asasi manusia seluruh warga negara.

Bila peserta anggota legislatif, Pasangan calon Presiden dan Wakil Presiden dan pasangan calon Gubernur dan Wakil Gubernur/ Walikota dan Wakil Walikota/ pasangan calon Bupati dan Wakil Bupati, keberatan atas hasil penetapan oleh KPU maka dapat diselesaikan di Mahkamah Konstitusi untuk mendapatkan keadilan dalam hak-hak berdemokrasi.
Dalam melindungi hak-hak warga negara dalam Pemilu maupun Pemilukada Mahkamah telah memutuskan bahwa calon itu selain dari Partai Politik bisa juga dari 'Independen' yang berasal dari tokoh agama, tokoh adat dan pimpinan organisasi tertentu yang mempunyai pengaruh dalam masyarakat. Demikian halnya dengan putusan Mahkamah Konstitusi tentang penambahan syarat-syarat seorang pemilih yaitu bisa menggunakan KTP, SIM atau tanda pengenal lain asal yang bersangkutan dapat mengikuti pesta demokrasi tersebut.

Ini merupakan langkah luar biasa yang Mahkamah Konstitusi buat dalam rangka melindungi hak asasi warga negara dalam mengikuti pesta demokrasi.

Salah satu tonggak baru reformasi UU adalah dengan ditetapkannya UU No. 4 Tahun 2004 dimana telah diatur Prolegnas yang kemudian diatur lebih lanjut dengan PP No. 61 Tahun 2005 tentang tata cara penyusunan dan pengelolaan Prolegnas. Pasal 15 UU No. 10 Tahun 2004 menetukan bahwa perencanaan UU dan Perda dilakukan dalam sustu Prolegnas dan Prolegda.

Pasal 1 Angka 9 UU No. 10 Tahun 2004 menyebtkan bahwa Prolegnas adalah instrumen perencanaan pembentukkan UU yang disusun secara berencana, terpadu dan sistematis yang memuat potret perencanaan hukum dalam periode tertentu disertai prosedur yang harus ditempuh dalam pembentukkannya.

Prolegnas memuat daftar dan skala prioritas program legislasi jangka menengah dan tahunan yang disusun secara berencana, terpadu dan sistematis oleh DPR RI bersama dengan Pemerintah sesuai dengan perkembangan kebutuhan hukum masyarakat dalam mencapai tujuan negara pada tahap dan periode tertentu.

Secara operasional Prolegnas memuat daftar RUU yang disusun berdasarkan metode dan parameter tertentu serta dijiwai oleh visi dan misi pembanguan hukum nasional.

Keharusan adanya Prolegnas dan Prolegda dimaksudkan agar semua UU dan Perda yang dibuat dapat dinilai lebih dulu kesesuaian 
dengan Pancasila dan UUD 1945 melalui perencanaan dan pembahasan matang. Didalam Prolegnas dan Prolegda diatur pula mekanisme pembuatan UU maupun Perda yang tidak boleh dilanggar. Misalnya dalam membuat RUU maka agar supaya layak untuk diajukan ke DPR sebagai prioritas Prolegnas dari Pemerintah, harus memuat Pertama, Naskah Akademik; Kedua, telah disusun dalam bentuk RUU; Ketiga, telah diharmonisasikan yaitu dibahas dalam forum antara Departemen.

Prolegnas merupakan Politik Hukum Nasional. Peran Mahkamah Konstitusi sebagai pengawal dalam Prolegnas adalah melakukan Judicial review terhadap UU yang tidak memenuhi syarat formal yakni tidak sesuai dengan mekanisme pembuatan UU yang terdapat dalam pasal 17 ayat (1) UU No. 10 Tahun 2004 bahwa setiap RUU baik yang dari DPR maupun Pemerintah harus disusun di dalam Prolegnas. Mahkamah Konstitusi dapat menguji secara formal UU tersebut dan bila materi muatahnnya bertentangan dengan Pancasila dan UUD 1945 maka Mahkamah Konstitusi dapat melakukan judicial review terhadap UU tersebut. Keputusan Mahkamah Konstitusi berkaitan dengan uji formal maupun uji materiil dari sebuah UU adalah membatalkan pemberlakukan UU tersebut.

Pengecualian syarat formal dengan alasan tertentu Prolgenas dapat disisipi dengan RUU baru jika ada alasna-alasan yang kuat yaitu karena ada putusan Mahkamah Konstitusi yang menyebabkan terjadinya kekosongan hukum yang bharus segera diisi karena ada Perpu yang mau atau tidak mau harus dibahas pada persidangan DPR berikutnya, kartena ada perjanjian Internasional yang harus diretifikasikan dalam waktu singkat dan karena keadaan luar biasa, keadaan konflik atau bencana alam serta karena alasan keadaan tertentu lainnya yang memastikan adanya urgensi nasional atas suatu RUU baru yang dapat disetujui bersama oleh Badan Legislatif DPR dan MenHuk-Ham.

Alasan diatas secara formal tidak akan di judicial review hanya saja diuji secara $m$ ateri atau substansi dari UU tersebut. Keputusan judicial oleh Mahkamah Konstutusi dapat membatalkan pemberlakukan UU dimaksud.

Dengan demikian Prolegnas dan Prolegda menjadi penyaring isi (penuangan) Pancasila dan UUD 1945, dimana UU dan Perda mempunyai 2 (dua) fungsi yaitu pertama, sebagai potret rencana hukum untuk mencapai tujuan negara yang sesuai dengan Pancasila, UUD 1945 dan sistem hukum nasional selama lima tahun. Disini rencana isi hukum dapat dibicarakan lebih dulu agar sesuai dengan Pancasila dan Kaidah-kaidah penuntun hukumnya. Kesalahan isi peraturan perundangundangan dalam arti Prolegnas yang pertama dapat dibatalkan dengan pengujian judicial melaui uji materiil; Kedua, sebagai mekanisme atau prosedur pembuatan peraturan perundang-undangan agar apa yang telah ditetapkan sebagai rencana dapat dilaksanakan dengan prosedur dan mekanisme yang benar. Kesalahan dalam prosedur pembentukkan peraturan perundang-undangan dalam arti Prolegnas yang kedua ini dapat dibatalkan dengan pengujian judicial melalui uji formal.

Oleh karena itu peran Mahkamah konstitusi dalam mewujudkan dan mempertahankan Pancasila dan UUD 1945 dalam Prolegnas sangat besar dengan cara melakukan judicial review secara formal maupun secara materiil dari sebuah UU.

\section{Mahkamah Konstitusi sebagai Penegak Kons- titusi}

Berdasar kewenangan Mahkamah Konstitusi sebagaimana tercantum dalam Pasal 24C ayat (1) UUD 1945 dan UU No. 12 Tahun 2008, maka Mahkamah Konstitusi berwenang mengadili pada tingkat pertama dan terakhir yang putusannya bersifat final untuk menguji UU terhadap UUD 1945, memutus sengketa kewenangan lembaga negara yang kewenangannya diberikan oleh UUD 1945, memutus pembubaran partai politik, memutus perselisihan tentang hasil pemilu dan Pemilukada dan wajib memberi putusan atas pendapat DPR bahwa Presiden dan/atau Wakil Presiden diduga telah 
melakukan pelanggaran hukum berupa pengkhianat terhadap negara, korupsi, penyuapan, tindaka pidana berat lainnya, tau perbuatan tercela, dan/atau tidak lagi memenuhi syarat sebagai Presiden dan/atau Wakil Presiden sebagaimana dimaksud dalam UUD 1945 (pasal 6 UUD 1945). Selain itu Mahkamah Konstitusi memerlukan kewenangan untuk menangani pengaduan konstitusional (constitutional complaint) dalam rangka membangun sistem ketatanegaraan berdasarkan konstitusi yang patuh pada landasan hukum demokratis. ${ }^{14}$

Penyelesaian permohonan perkara yang diajukan kepada Mahkamah Konstitusi oleh pemohon, bila ada keputusan Hakim yang berkekuatan hukum tetap tidak ada upaya hukum lain yang ditempuh seperti yang dikenal pada kekuasaan kehakiman dibawah Mahkamah Agung. Hal ini menunjukan bahwa Mahkamah Konstitusi sebagai peradilan ketanegaraan tetap mempertahankan eksistensi konstitusi (UUD 1945) sebagai hukum negara yang tertinggi karena di dalam UUD 1945 mengatur tentang Pancasila sebagai dasar negara, tujuan negara, bentuk negara dan sistem pemerintahan, Hak Asasi Manusia dan kewenangan lembaga-lembaga negara dan hubungannya antara satu sama lain.

Pancasila secara konkrit terdapat dalam pembukaan UUD 1945. Hal ini bila dikaitkan dengan teori Hans Kelsen tentang Grundnorm dan Stufenbaund Theory, maka Grundnorm adalah Pancasila sebagai cita-cita moral bangsa yang berada diluar sistem norma hukum yang berfungsi sebagai konstitutif regulative terhadap norma-norma yang ada dalam sisitem hukum sedangkan Pancasila sebagai dasar negara (Staatsfundamentalnorm) tercantum dalam pembukaan UUD 1945 dan Stufenbaund Theory (bangunan berjenjang) kemudian dikembangkan oleh Hans Nawiasky dengan Theory von Stufenbaund der Rechtssordnung bila dikaitkan dengan tata urutan peraturan perundang-undangan dalam sistem hukum Indonesia sebagaimana

14 Moh Mahfud MD, 2010, Mendesak Kewenangan Konstitusional MK, http:// regional. kompas.com/read / 2010/ 10/ 23034852/ Mendesak. . kewenangan. konstitusio nal.MK, diakses pada tanggal 4 Februari 2011 diatur dalam Tap MPR No. II/MPR/ 2000 tentang sumber tertib hukum dan tata urutan peraturan perundang-undang dan UU No. 10 Tahun 2004 tentang pembentukkan peraturan perundangundangan bahwa hierarkhis peraturan perundang-undangan adalah sebagai berikut: UUD 1945, Ketetapan MPR, UU/Perpu, Peraturan Pemerintah, Peraturan Presiden, dan Peraturan Daerah

Jika dihubungkan dengan teori Hart tentang Ultimate Rules of Recognition bahwa petunjuk atau norma pengenal yang paling akhir (ultimate Rules of Recognition) menjadi norma dasar dalam pembentukkan peraturan perundang-undangan ditentukan dalam UUD ${ }^{15}$. Oleh karena itu yang menjadi norma dasar adalah UUD 1945. Dari uraian diatas UUD 1945 sebagai norma dasar harus terus dipertahankan eksistensinya karena didalamnya tercantum dasar negara yakni Pancasila sehingga dalam hal ini Mahkamah Konstitusi berfungsi untuk menegakkan UUD 1945 dengan melakukan judicial review atas UU yang bertentangan terhadap UUD 1945 maupun dalam melakukan kewenangan lainnya sebagai pengawal politik hukum nasional, pengawal konstitusi dan sebagai penafsir tunggal pasal-pasal UUD 1945 demi tegaknya hukum dan keadilan.

Mahkamah Konstitusi sebagai penegak konstitusi juga sebagai lembaga negara pengawal konstitusi atau The Guardian and the interpreter of the constitution. ${ }^{16}$ Berkaitan dengan masa depan lembaga Mahkamah Konstitusi, maka terdapat 2 (dua) hal yang sangat urgen sehingga Mahkamah Konstitusi benarbenar dapat menjadi lembaga penegak Konstitusi yakni Mahkamah Konstitusi sebagai Pemegang Kekuasaan Kehakiman yang melakukan judicial review atas UU dan Mahkamah Konsti-

15 Lihat H.L.A. Hart, 1972, The Concept of Law, London: Oxford University Press, hlm. 25, dalam Theo Huij bers, 1982, Filsafat Hukum Dalam Lintasan sejarah, Yogyakarta : Kanisius, hlm. 43

16 Pan Mohamad Faiz Kusumawijaya, 2006, Mahkamah Konstitusi: The Guardian and The Interpreter of the Constitution, http:// jurnalhukum. blogspot.com/ 2006/09/mahkamah-konstiusi-ri.html, diakses tanggal 4 Februari 2011 
tusi sebagai Lembaga Penegak Hukum Konstitusi Dalam Mencapai Keadilan Substansi yang Progresif.

\section{Mahkamah Konstitusi sebagai Pemegang Ke- kuasaan Kehakiman yang Melakukan Judicial Review atas UU}

Kewenangan jiducial review dalam kekuasaan kehakiman dilakukan oleh dua lembaga yaitu Mahkamah Konstitusi dan Mahkamah Agung. J udicial review UU terhadap UUD 1945 menjadi kewenangan Mahkamah Konstitusi sedangkan Judicial Review peraturan perundangan dibawah UU menjadi kewenangan Mahkamah Agung. Judicial review dilakukan baik secara formal dan materiil. Hak menguj i formal adalah kewenangan untuk menilai peraturan perundang-undangan terhadap UUD sedangkan hak menguji materiil adalah hak yang dimiliki oleh hakim, dan lembaga negara lain seperti eksekutif dan legislatif.

Pada intinya, Judicial review dilakukan terhadap semua peraturan perundang-undangan dengan melihat apakah bertentangan dengan peraturan setingkat diatasnya dimana aturan tersebut pada akhirnya dijudicial review apakah bertentangan dengan UUD ataukah tidak. Kewenangan untuk melakukan judicial review dalam kekuasaan kehakiman yang dilakukan oleh 2 (dua) lembaga tinggi negara yakni Mahkamah Konstitusi dan Mahkamah Agung harus diserahkan pada salah satu lembaga tinggi negara agar lembaga tersebut dalam mejudicial review benar-benar dilakukan dengan melihat apakah peraturan daerah bertentangan dengan UU atau UU bertentangan dengan UUD. Berkaitan dengan hal diatas maka yang menjadi lembaga pemegang kekuasaan kehakiman untuk melakukan judicial review adalah Mahkamah Konstitusi sedangkan Mahkamah Agung hanya berwenang menyelesaikan kasus-kasus perdata, pidana yang berkaitan dengan orang/badan hukum perdata/lembaga dan yang merugikan kepentungan umum/ pribadi.

Hal yang mendasar dari Mahkamah Konstitusi sebagai satu-satunya pemegang kekuasaan judicial review adalah sebagai berikut. Per- tama, UU dan Peraturan daerah masuk dalam Prolegnas dan Prolegda sebagai perwujudan sistem politik hukum Indonesia dimana Mahkamah Konstitusi sebagai pengawal politik hukum mulai dari proses inisiatif, pembuatan, perancangan, naskah akademik sampai RUU dan Raperda diajukan ke DPR/DPRD untuk dimasukkan ke dalam Prolegnas dan Prolegda sampai kepada pembahasan dan penetapan menjadi UU dan Raperda dan implementasinya oleh penegak hukum. Bila selama proses tersebut tidak sesuai dengan UUD maka Mahkamah Konstitusi dapat melakukan judicial review secara uji formal maupun uji materiil terhadap UU dan Peraturan Daerah. Kedua, setelah otonomi daerah di mana kewenangan penuh diserahkan kepada daerah Kabupaten/Kota, banyak Perda yang dibuat yang bertentangan dengan UUD 1945 bahkan mengancam disintegrasi bangsa. Contohnya Perda di Papua yang mengharuskan dalam pasangan calon Bupati dan wakil bupati adalah Orang asli Papua Ras Melanesia. hal seperti ini sebaiknya dilakukan Judicial Review oleh Mahkamah Konstitusi karena dia diberi kewenangan untuk mempertahankan dan menegakkan Konstitusi (UUD 1945), karena kalau dilakukan di Mahkamah Agung harus melakukan judicial review Perda terhadap UU dan sampai disitu dan itu memakan waktu yang lama sehingga kalau ditangan Mahkamah Konstitusi maka Judicial Review dilihat apakah pemberlakuan Perda bertentangan dengan UUD dengan proses hukum yang cepat, tepat dan biaya murah.

Ketiga, sekedar melihat sejarah pembentukkan Mahkamah Konstitusi dimana meskipun Indonesia tidak mengenal pemisahan kekuasan negara antara eksekutif, legislatif dan yudikatif seperti teori Trias Politica dari Aristoteles, namun karena pertimbangan meningkatnya mafia Peradilan dan Mafia penegak hukum dan adanya penafsiran ganda terhadap Konstitusi maka untuk mengatasi hal itu dibentuklah Mahkamah Kostitusi. Berarti Mahkamah Agung belum bisa memperbaiki mafia peradilan yang selama ini ada sehingga memunculkan ketidak percayaan masyarakat pada lembaga Mahkamah 
Agung oleh karena itu lebih baiknya berkaitan dengan judicial review UU dan Peraturan Daerah di berikan kepada kewenangan Mahkamah Konstitusi sebagai penegak konstitusi. Keempat, untuk menghindari tumpang tindih kewenangan tentang J udicial Review yang ada pada Mahkamah Konstitusi dan Mahkamah Agung agar supaya kewenangan tersebut diberikan hanya pada Mahkamah Konstitusi. Kelima, agar supaya dalam melakukan judicial review Mahkamah Konstitusi akan melihat secara runtun terhadap UU dan Perda yang bertentangan dengan UUD 1945.

Untuk mewujudkan Mahkamah Konstitusi sebagai satu-satunya pemegang kekuasaan kehakiman yang berkaitan dengan judicial review, maka perlu diwujudkan adanya Amandemen Ke-V UUD 1945. Beberapa hal tersebut di atas dapat menjadi pertimbangan dalam perubahan kewenangan Mahkamah Konstitusi dan Mahkamah Agung sebagai pemegang kekuasaan kehakiman sebagaimana diatur dalam Pasal 24 UUD 1945.

\section{Mahkamah Konstitusi sebagai Lembaga Pene- gak Hukum Konstitusi Dalam Mencapai Keadil- an Substansi yang Progresif}

Banyak nama yang diberikan kepada Mahkamah Konstitusi seperti sebagai pengawal politik hukum nasional, pengawal konstitusi, pengawal demokrasi, Penafsir tunggal pasalpasal UUD 1945. Namun dalam tulisan ini penulis lebih melihat Mahkamah Konstitusi sebagai penegak hukum kontitusi. Dasar pemikirannya adalah sebagai berikut. Pertama, sebagai penegak hukum bukan saja Mahkamah Konstitusi melakukan judicial review tetapi memutus perkara lain yang menjadi kewenangannya yaitu memutus sengketa antar lembaga, memutus sengketa hasil Pemilu dan Pemilukada dan kewajibannya memutus pendapat DPR atas Presiden dan Wakil Presiden yang berkaitan dengan impeachment. Kedua, Mahkamah Konstitusi merupakan salah satu lembaga negara yang melakukan kekuasaan kehakiman yang merdeka untuk menyelenggarakan peradilan guna menegakkan hukum dan keadilan. Menye- lenggarakan peradilan inilah guna menegakkan hukum dan keadilan inilah yang menunjukan lembaga negara Mahkamah Konstitusi sebagai lembaga penegak hukum konstitusi disamping penegak hukum yang lainnya seperti Mahkamah Agung, KPK, Komisi Yudisial, Kepolisian, Kajaksaan dan Advokat.

Kehadiran Mahkamah Konstitusi sebagai lembaga penegak hukum adalah ditujukan kepada warga negara yang mencari keadilan karena hak-hak asasinya dilanggar oleh berlakunya suatu UU. Keadilan yang diperoleh oleh pencari keadilan adalah keadilan substansi bukan keadilan prosedural. Keadilan substansi inilah yang diterapkan oleh Mahkamah Konstitusi dalam setiap putusan perkara yang menjadi kewenangannya.

Berdasar pada putusan-putusan Mahkamah Konstitusi maka keadilan substansilah yang diutamakan dari keadilan prosedural yang hanya berpedoman pada teks atau bunyi pasalpasal UU. Mahkamah Konstitusi dalam setiap putusannya telah menerapkan hukum progresif itu dengan lebih memutuskan perkara atau sengketa berdasarkan moral dan hati nurani. Jadi, dalam setiap putusannya sudah keluar dari konteks positivistik dan lebih melihat pada keadilan substansi. Contoh kasus adalah putusan Mahkamah Konstitusi tentang Pemilukada Kab. Puncak Jaya dimana pemungutan suara menggunakan sistem "noken" dan itu mereka bahwa pola demokrasi seperti itu adil dan Mahkamah Konstitusi menolak gugatan pemohon dan menangkan termohon yakni KPUD yang menangkan sistem pemilihan suara dalam bentuk "noken". Contoh lain adalah menambah syarat-syarat sebagai pemilih tetap dalam Pemilu dan Pemilukada yaitu pemilih bisa menggunakan KTP atau Paspor yang sebenarnya tidak diatur dalam UU Pemilu.

Mahkamah Konstitusi sebagai pangawal demokratis dan penegak konstitusi telah membuat keseimbangan antara demokratis (kedaulatan rakyat) dan nomokrasi (kedaulatan hukum). Bila terjadi ketidakseimbangan antara keduanya dimana dalam proses demokrasi baik Pemilu maupun politik hukumnya bertentangan 
dengan Pancasila dan UUD 1945, maka Mahkamah Konstitusilah yang berperan dalam menjalankan kewenangannya untuk melakukan judicial review. Hal ini dimaksudkan agar demokrasi dan politik hukumnya tidak melenceng dari Pancasila dan UUD 1945.

Terdapat beberapa Putusan MK selama 2009 yang mencerminkan MK sebagai lembaga pengawal demokrasi dan penegak keadilan substantif antara lain sebagai berikut. (a) Putusan perkara pilpres yang dimohonkan oleh J K-WIN dan Mega-Prabowo (Perkara No.108-109 / PHPU.B-VII/ 2008); (b) Penegasan Putusan Final Pemilukada Jawa Timur (Perkara No. 41/ PHPU.D-VI/ 2008); (c) Pemilukada Bengkulu Selatan Batal Demi Hukum (Perkara No. 57/ PHPU. D-VII/ 2008); (d) Pemungutan Suara Ulang Nias Selatan (perkara No. 28-65-70-82-84-89/ PHPU. C-VII/ 2009); (e) Pemilu Sesuai Budaya Setempat di Yahukimo; ( $f$ ) Putusan Sela atas perkara PHPU legislatif di berbagai daerah; (g) Putusan Akhir Pelaksanaan Putusan MK; (h) Tafsir Penghitungan Tahap Ketiga (Perkara No.74-94-8059-67/ PHPU.C-VII/ 2009); (i) Penghitungan Tahap Kedua Konstitusional Bersyarat, Konstitusionalitas Parliamentary Threshold 2,5\% Presidential Threshold 20\%dan Pemisahan Jadwal Pemilu (Perkara No.3/ PUU-VII/ 2009; (j) Terpidana Dapat Menjadi Caleg (Perkara No.04/ PUUVII/ 2009); (k) Tafsir Pasal "Penyebaran Kebencian" KUHP (Perkara No. 7/ PUU-VII/ 2009); (I) Larangan Publikasi Quick Count Inkonstitusional (Perkara No.9/PUU-VII/ 2009); (m) KTP dan Paspor sebagai Identitas Pemilih (Perkara No. 102/ PUU-VII/ 2009); (n) Anggota DPD berhak menjadi Ketua MPR (Perkara No.117/PP-VII/ 2009); dan (o) Kasus uj i materil UU KPK dengan Pemohon Bibit-Chandra (Perkara No.133/ PUUVII/ 2009). Dengan demikian Mahkamah Konstitusional mempunyai peranan penting dalam menegakkan demokrasi dan nomokrasi sebagai ciri negara hukum yang demokratis yang menjunjung tinggi hak asasi, hukum dan keadilan.

\section{Penutup}

Simpulan
Penuangan prinsip demokrasi dan nomokrasi dalam Undang-Undang Dasar 1945 (UUD 1945) mencerminkan adanya pelaksanaan demokrasi yang harus berdasarkan pada prinsip nomokrasi yakni negara berdasarkan atas hukum. Pelaksanaan prinsip demokrasi dan nomokrasi pasca amandemen UUD 1945, telah terlihat perubahan dalam proses demokrasi dengan sistem pemilihan Presiden dan Wakil Presiden dan kepala daerah yang dilakukan secara langsung oleh rakyat dan dilaksanakan oleh Komisi Pemilihan Umum (KPU) dan penegakan nomokrasi dengan ditandai lahirnya lembaga baru yaitu Mahkamah Konstitusi sebagai pengawal dan penegak konstitusi dalam bentuk hak judicial review atas undang-undang, di samping lembaga-lembaga negara lainnya.

Proses pembuatan dan implementasi undang-undang (UU) yang merupakan produk politik tidak boleh bertentangan dengan konstitusi atau UUD 1945. Bila suatu UU bertentangan dengan konstitusi maka Mahkamah Konstitusi (MK) akan melakukan judicial review atas UU tersebut. Hal ini dimaksudkan untuk tetap menegakkan konstitusi. Demikian halnya dengan pelaksanaan demokrasi dimana dengan

Pemilihan presiden dan Wakil Presiden dan Kepala daerah dan Wakil Kepala Daerah yang dipilih secara langsung oleh seluruh rakyat maka dalam pelaksanaan demokrasi tetap menjunjung tinggi hukum itu dan bila pelaksanaannya bertentangan dengan UUD 1945 maka dapat diajukan ke mahkamah konstitusi untuk diputuskan sengketa pemelihan Umum dan pemilihan umum kepala daerah (pemilukada). MeIalui judicial review, Mahkamah Konstitusi tetap mempertahankan konstitusi agar supremasi hukum tetap berada diatas dan tidak terpengaruh oleh pelaksanaan demokrasi yang ada. Artinya Mahkamah Konstitusi sebagai lembaga penegak konstitusi akan melakukan judicial review terhadap setiap keputusan KPU dan UU yang bertentangan dengan UUD 1945. Dengan demikian demokrasi tidak berjalan diluar dari ketentuan yang diatur dalam pasal-pasal UUD 1945 sehingga akan menghasilkan keputusan yang berkeadilan substantif. 


\section{Daftar Pustaka}

Djauhari. "Konsep Negara Kesejahteraan Pra Kemerdekaan RI". J urnal Hukum Vol. 16 No. 2 J uni 2006, FH UNISULA Semarang;

Erwiningsing, Winahyu. "Mahkamah Konstitusi (Telaah Terhadap Putusan Mahkamah Konstitusi dan Fungsi Mahkamah Konstitusi dalam Reformasi Hukum)". J urnal Ilmu Hukum, Vol. 9 No 1 2006, Fakultas Hukum UMS Surakarta;

Fatkhurohman. "Memahami Pembubaran Partai Politik Era Orde Lama Di Indonesia". Jurnal Media Hukum 16 (2) Desember 2009. FH Universitas Muhammadiyah Yogyakarta;

Fauzan, Muhammad. "Eksistensi Komisi Yudisial Dalam Struktur Ketatanegaraan Republik Indonesia dan yang Seharusnya Diatur Dalam Peraturan Perundang-undangan", J urnal Dinamika Hukum Vol 8 No 1 2008, Fakultas Hukum UNSOED Purwokerto;

Hart, H.L.A. 1972. The Concept of Law. London: Oxford University Press;

Hasnati. "Pertautan Kekuasaan Politik dan Negara Hukum". Jurnal Hukum Respublica Vol. 3 No 1 Tahun 2003, Fakultas Hukum Universitas Lancang Kuning Pekanbaru;

Hidayat, Arief. Bernegara Itu Tidak Mudah (Dalam Perspektif Politik Dan Hukum). Pidato Pengukuhan Guru Besar Dalam IImu Hukum FH Undip Semarang, 4 Februari 2010;

Huijbers, Theo. 1982. Filsafat Hukum Dalam Lintasan sejarah. Yogyakarta : Kanisius;

Kusumawijaya, Pan Mohamad Faiz. 2006, Mahkamah Konstitusi: The Guardian and The Interpreter of the Constitution, http:// jurnalhukum. blogspot.com/2006/ 09/ ma hkamah-konstiusi-ri.html, diakses tanggal 4 Februari 2011;
Masyithoh, Novita Dewi. “Kebijakan Pemerintah Daerah dalam Pemberdayaan Ekonomi Perempuan Sebagai perwujudan Ekonomi Kerakyatan (Studi Kelompok Wanita Tani Ngaliyan Kecamatan Limpung Kabupaten Batang)". Jurnal Law Reform Pembaharuan Hukum, Vol. 3 No. 2 Oktober 2007, Program Magister IImu Hukum Semarang;

MD, Moh Mahfud. 2010, Mendesak Kewenangan Konstitusional MK, http:// regional.kom pas.com/ read / 2010/10/23034852/ Mendesak. kewenangan. konstitusional.MK, diakses pada tanggal 4 Februari 2011;

2006. Membangun Politik Hukum Menegakkan Konstitusi. Jakarta: Pustaka LP3ES Indonesia;

Sitabuana, Tundjung $\mathrm{H}$. "Politik Hukum PenyeIesaiaan Masalah Cina Di Indonesia Pada Era Global". Jurnal Masalah-Masalah Hukum Vol. 37 No. 1 Maret 2008, FH Universitas Diponegoro;

Suripto. "Wewenang Mahkamah Konstitusional menguji UUD (J udicial Review)". Jurnal Negarawan, 21 J uni 2007, Sekretaris Negara Republik Indonesia;

Utama, Yos Johan. Membangun Peradilan Tata Usaha Negara Yang Berwibawa. Pidato Pengukuhan Guru Besar Dalam IImu Hukum Undip Semarang, 4 Februari 2010;

Wijayanti, Septi Nur. "Studi Evaluasi Terhadap Amandemen UUD 1945 (Amandemen Sebagai Upaya Pemenuhan Kebutuhan $\mathrm{Hu}-$ kum Masyarakat Indonesia)". J urnal Media Hukum Vol. 16 No. 2 Desember 2009, $\mathrm{FH}$ Universitas Muhammadiyah Yogyakarta;

Zulfirman. "Ontologi Demokrasi". Jurnal Hukum Vol. 14 No. 2 J uni 2006, FH (UNISULA) Semarang. 